http://jmscr.igmpublication.org/home/ ISSN (e)-2347-176x ISSN (p) 2455-0450

crossref DOI: https://dx.doi.org/10.18535/jmscr/v8i2.60

\title{
Histopathological profile of ovarian tumors in a tertiary care centre in Kerala: a retrospective two year study
}

\author{
Authors \\ Dr Sheela K. M1 ${ }^{1}$, Dr Mithila Mohan ${ }^{2}$ \\ ${ }^{1}$ Associate Professor (Non cadre), ${ }^{2}$ Senior Resident \\ Government Medical College, Thiruvananthapuram, India
}

\begin{abstract}
Background: Ovarian tumors account for $30 \%$ of all cancers of female genital tract which represents the seventh most common cause of cancer and fourth leading cause of death in women. The present study was done with an objective to analyze the frequency of histopathological spectrum of ovarian tumors in our department.

Method: The present two year retrospective study was carried out in the department of Pathology, Government Medical College, Trivandrum from January 2015 to December 2016.

Results: In this study a total of 597 histopathologically proven ovarian tumors were included. These were removed from 570 patients. 27 of them had bilateral ovarian tumors. Majority of ovarian tumors were seen in the age group of 40-49 years (24\%) and least below 10 years $(0.3 \%)$. The most common ovarian tumor encountered was surface epithelial tumor (79\%), followed by germ cell tumors (25.5\%), sex cord stromal tumors (4.2\%), metastasis (0.34\%). Serous cystadenoma was the most common surface epithelial tumor (36.7\%) and among germ cell tumors, benign cystic teratoma was commonest (24.12\%), adult granulosa cell tumors among sex cord stromal tumors (1.51\%). In the present study, $85 \%$ cases were benign tumors, $3.34 \%$ were borderline tumors and $11.6 \%$ were malignant tumors. Commonest clinical presentation for both benign and malignant tumors was abdominal pain followed by mass abdomen.

Conclusion: The majority of ovarian tumors in our study were benign and unilateral. Most common age group with ovarian tumors was 40-49 years .

Keywords: Benign, malignant surface epithelial tumors, Histopathology.
\end{abstract}

\section{Introduction}

Ovarian cancer is the most lethal gynecological malignancy and ranks overall seventh most common cause of cancer ${ }^{1}$. Ovaries are intrapelvic organs of the reproductive system and are common sites for both benign and malignant neoplasms in all age groups from intrauterine period to post menopausal age group ${ }^{2}$. The ovary consists of both totipotent sex cells and multipotent mesenchymal cells and when it becomes neoplastic almost any type of tumor can thus result ${ }^{3}$. The histiogenesis of ovarian tumors rests around the four main components namely surface epithelium, germ cells, sex cord and specialized ovarian stromal tissue ${ }^{4}$.

Ovarian tumors have a wide spectrum of clinical and morphological features. They pose many challenges in diagnosis for both gynecologist and pathologist due to its morphological diversity. The increased risk of ovarian cancer particularly of surface epithelial tumors (SET) is associated with use of hormone replacement therapy, tobacco consumption, family history of ovarian and breast cancers and mutations of BRCA1 and BRCA2. $5,6,7$ 
Ovarian tumors represent the greatest challenge to clinicians since it is very difficult to diagnose in its early stages due to non specific symptoms and asymptomatic nature in many of the cases. Advanced stage tumors are more easily diagnosed but carry a poor prognosis despite advanced surgery, chemotherapy and targeted therapy. Despite the new techniques in imaging and genetics, the diagnosis of ovarian tumors still depends on histopathological examination.

The present two year retrospective study was carried out to analyze the frequency and histopathological spectrum of ovarian tumors.

\section{Objective}

The aim of the study was to analyze the frequency of different histopathological types of ovarian tumors reported in Department of Pathology, Government Medical College Thiruvananthapuram for a period of two years.

\section{Materials and Methods}

The present retrospective two year study was carried out in the Department of Pathology Government Medical College Trivandrum, Kerala from January 2015 to December 2016. The study was started after approval from IRC and Human ethics committee .In this retrospective study, a total of 597 cases were included. These were removed from 570 patients. 27 of them had bilateral ovarian tumors. Paraffin embedded blocks of ovarian tumors were retrieved and 3- 5 micron thick sections were prepared, stained with $\mathrm{H} \& \mathrm{E}$. The clinical presentation and required data of the patients were recorded from archived case sheets. Special stains and immunohistochemistry were carried out in relevant cases. All the data were analyzed using Microsoft excel. The WHO classification of ovarian tumors $4^{\text {th }}$ edition has been used for categorizing the neoplasms.

\section{Inclusion Criteria}

All histopathologically proven cases of ovarian tumors received during the study period.

\section{Exclusion Criteria}

Non neoplastic lesions like endometriotic cyst and corpus luteal cyst, follicular cysts were excluded from the study.

\section{Results}

A total of 597 neoplastic ovarian tumors were studied. Of these, 543 cases were unilateral and 27 cases were bilateral.

Figure (1) showing age distribution of ovarian lesions

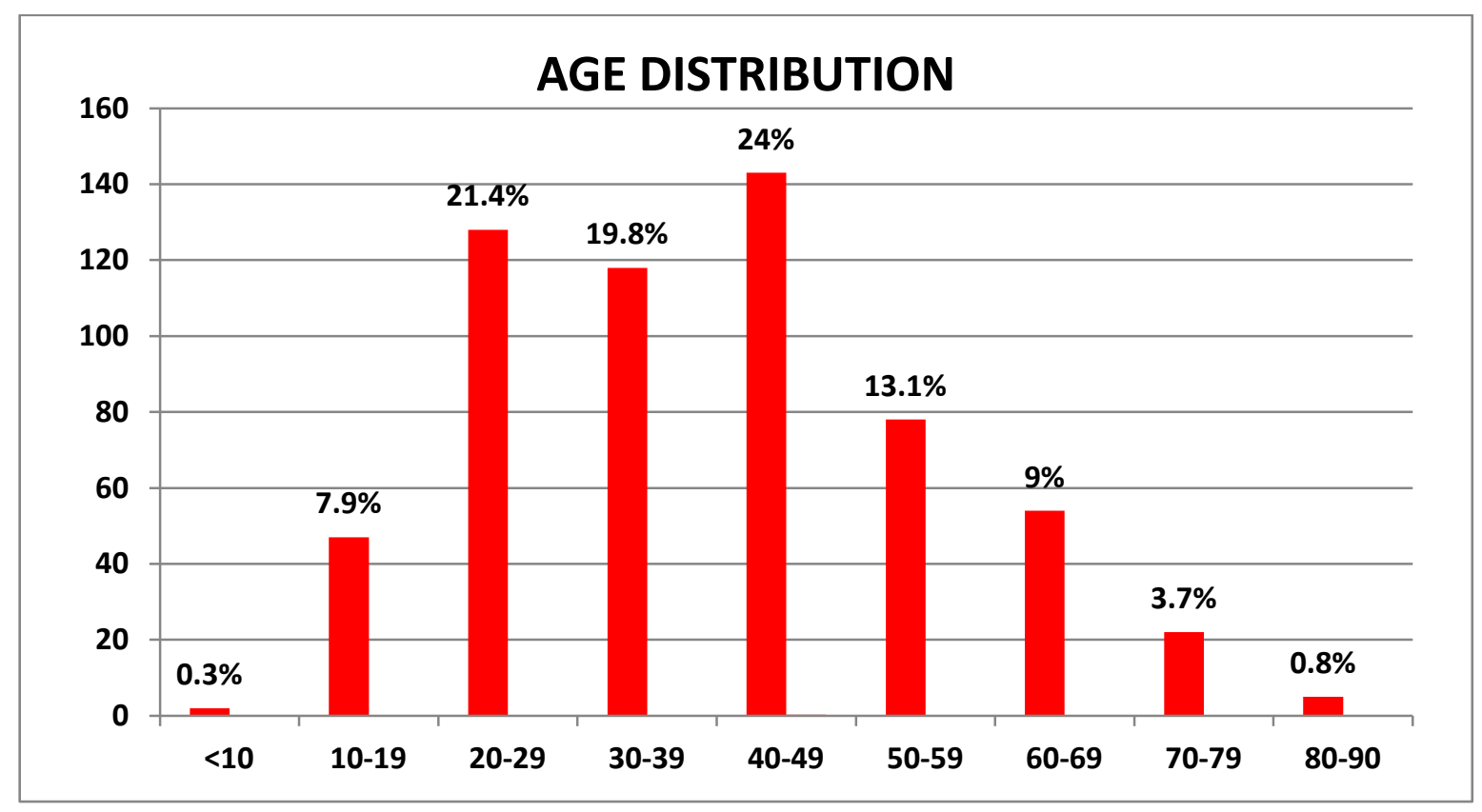

Figure 1

Maximum lesions were seen in the age group of 40-49years (24\%) and least below 10years $0.3 \%$. 


\section{JMSCR Vol||08||Issue||02||Page 334-342||February}

Table (1) Frequency distribution of tumors

Table 1

\begin{tabular}{|c|c|c|}
\hline NEOPLASM & Total & PERCENTAGE \\
\hline \multicolumn{3}{|l|}{ SURFACE EPITHELIAL TUMOURS } \\
\hline Serous cystadenoma & 219 & $36.68 \%$ \\
\hline Serous carcinoma - Low grade & 20 & $3.35 \%$ \\
\hline Serous carcinoma - High grade & 4 & $0.67 \%$ \\
\hline Mucinous cystadenoma & 117 & $19.60 \%$ \\
\hline Mucinous borderline tumour & 17 & $2.85 \%$ \\
\hline Mucinous carcinoma & 5 & $0.84 \%$ \\
\hline Seromucinous cystadenoma & 11 & $1.84 \%$ \\
\hline Seromucinous borderline tumour & 2 & $0.34 \%$ \\
\hline Clear cell carcinoma & 4 & $0.67 \%$ \\
\hline Sertoliformendometrioid carcinoma & 1 & $0.17 \%$ \\
\hline Endometrioidadenofibroma borderline & 1 & $0.17 \%$ \\
\hline Endometrioid adenocarcinoma & 9 & $1.51 \%$ \\
\hline Benign Brenner tumour & 3 & $0.50 \%$ \\
\hline Malignant Brenner tumour & 1 & $0.17 \%$ \\
\hline Malignant mixed surface epithelial tumor & 4 & $0.67 \%$ \\
\hline \multicolumn{3}{|l|}{ SEX CORD STROMAL TUMOURS } \\
\hline Adult granulosa cell tumour & 9 & $1.51 \%$ \\
\hline Fibrothecoma & 8 & $1.34 \%$ \\
\hline Fibroma & 4 & $0.67 \%$ \\
\hline Fibrosarcoma & 1 & $0.17 \%$ \\
\hline Steroid cell tumour & 1 & $0.17 \%$ \\
\hline Sex chord stromal tumour unclassified & 1 & $0.17 \%$ \\
\hline Poorly differentiated Sertolileydig cell tumour & 1 & $0.17 \%$ \\
\hline \multicolumn{3}{|l|}{ GERM CELL TUMOURS } \\
\hline Benign Mature cystic teratoma & 144 & $24.12 \%$ \\
\hline Immature teratoma & 3 & $0.50 \%$ \\
\hline Dysgerminoma & 3 & $0.50 \%$ \\
\hline Yolk sac tumour & 1 & $0.17 \%$ \\
\hline Malignant Mixed germ cell tumor & 1 & $0.17 \%$ \\
\hline \multicolumn{3}{|l|}{ METASTATIC TUMOURS } \\
\hline Metastasis & 2 & $0.34 \%$ \\
\hline Grand Total & 597 & $100 \%$ \\
\hline
\end{tabular}

The most common ovarian tumor was surface epithelial tumor 418 cases $(70 \%)$, followed by germ cell tumors 152 cases $(25.5 \%)$, sex cord stromal tumors 25 cases $(4.2 \%)$, metastasis 2 cases $(0.34 \%)$. Among the surface epithelial tumors, most common was serous cystadenoma 219 cases $(36.7 \%)$. Germ cell tumors commonest was benign mature cystic teratoma 144 cases (24.1\%). Among sex cord stromal tumors adult granulosa cell tumor was the commonest.

There were 27 cases of bilateral ovarian tumors.

Figure (2) showing nature of bilateral tumors. 


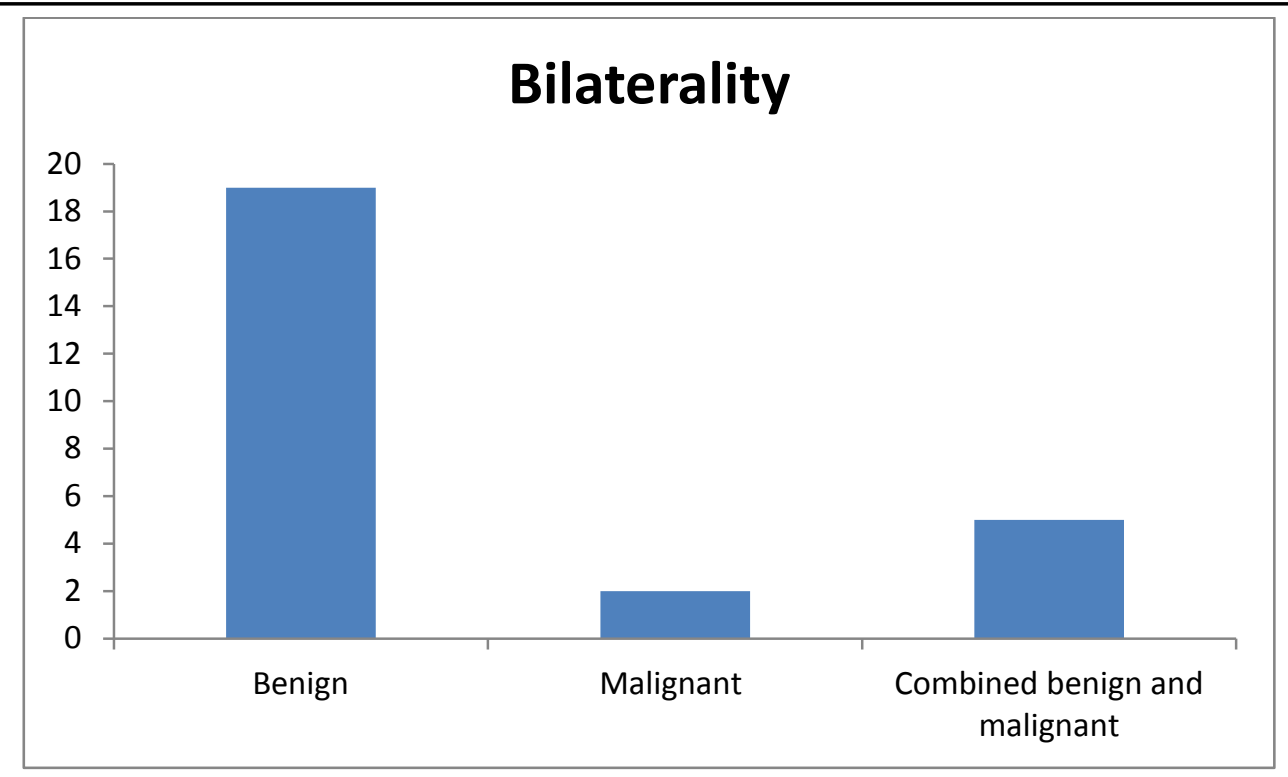

\section{Figure 2}

In 20 cases, both ovarian tumors were benign. In 2 cases both were malignant and 5 cases, one tumor was benign and other was malignant.
The most common presenting complaint was abdominal pain in 242 cases $(40.8 \%)$ followed by mass abdomen in 100 cases. (16.9\%)

Figure (3) showing the frequency distribution of symptoms in the study group

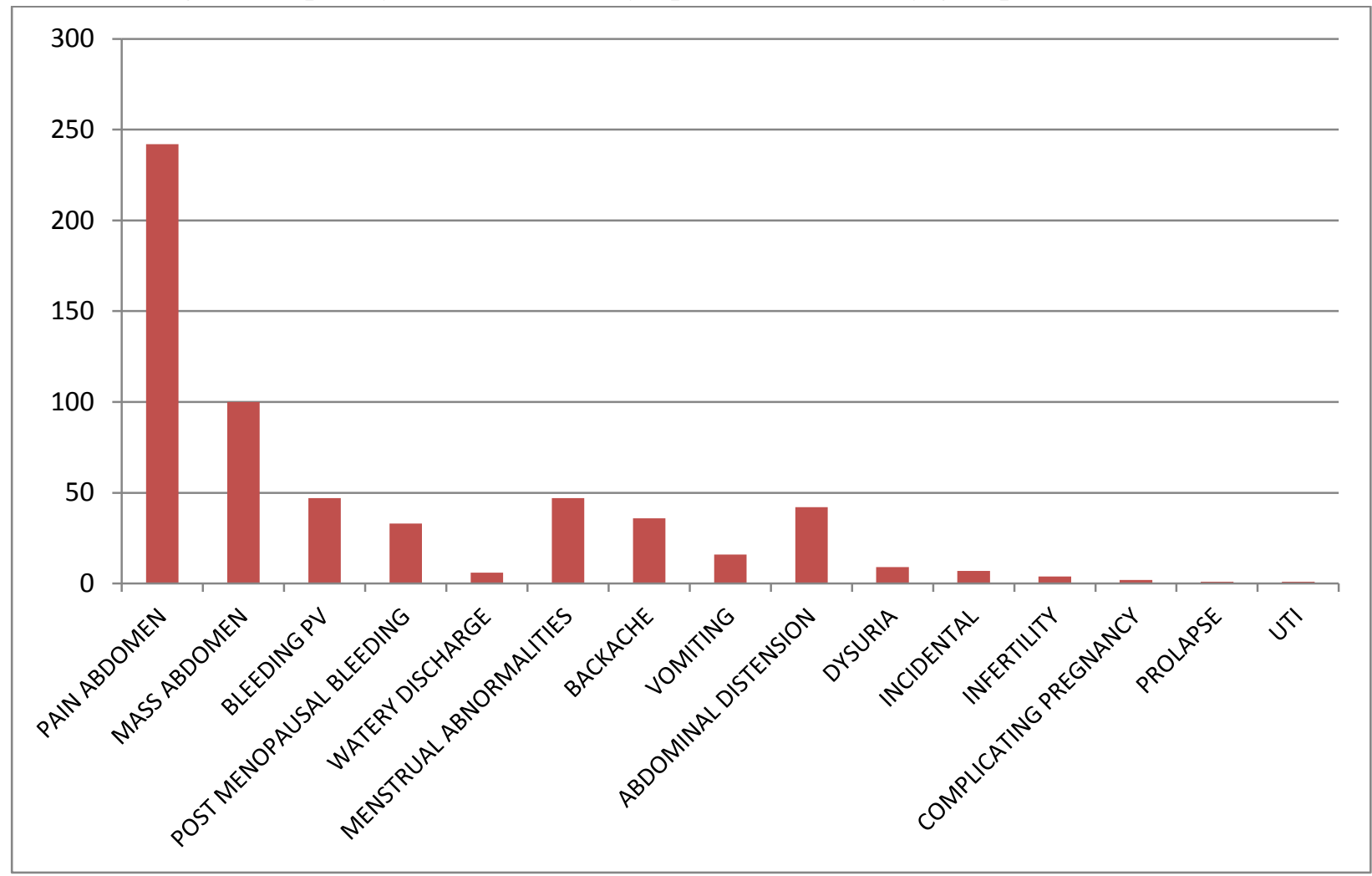

Figure 3

The youngest patient in our study was a 5year old girl with benign mature cystic teratoma and oldest was an $83 \mathrm{yr}$ old patient with mucinous cystadenoma.
The ovarian tumors were categorized into benign, borderline and malignant tumors. Benign tumors constituted 506 cases $(84.5 \%)$. Borderline tumors constituted 20 cases $(3.35 \%)$ and malignant 69 cases $(11.6 \%)$. 
Table (2) Frequency distribution of benign tumors

Table 2

\begin{tabular}{|l|c|c|}
\hline TUMORS & TOTAL & $\mathbf{\%}$ \\
\hline SURFACE EPITHELIAL TUMORS & $\mathbf{3 5 0}$ & $\mathbf{6 9 . 1}$ \\
\hline Serous cystadenoma & 219 & 43.28 \\
\hline Mucinous cystadenoma & 117 & 23.1 \\
\hline Seromucinous cystadenoma & 11 & 2.1 \\
\hline Benign Brenner tumour & 3 & 0.59 \\
\hline SEX CORD STROMAL TUMORS & $\mathbf{1 2}$ & $\mathbf{2 . 3 7}$ \\
\hline Fibrothecoma & 8 & 1.58 \\
\hline Fibroma & 4 & 0.79 \\
\hline GERM CELL TUMOURS & $\mathbf{1 4 4}$ & $\mathbf{2 8 . 4 5}$ \\
\hline Benign Mature cystic teratoma & 144 & 28.45 \\
\hline TOTAL & $\mathbf{5 0 6}$ & $\mathbf{1 0 0}$ \\
\hline
\end{tabular}

Figure (4) frequency of different borderline tumors

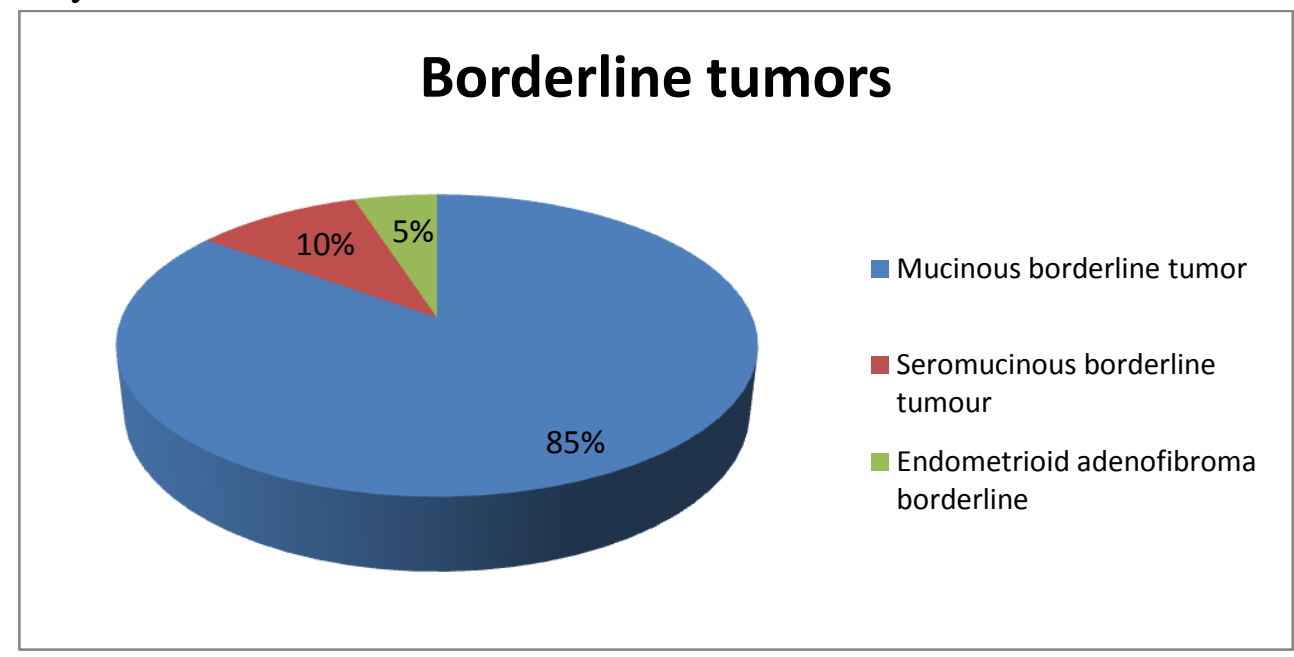

Figure 4

Table (3) frequency distribution of Malignant tumors

Table 3

\begin{tabular}{|l|c|c|}
\hline TUMORS & TOTAL & $\%$ \\
\hline SURFACE EPITHELIAL TUMORS & $\mathbf{4 8}$ & $69.6 \%$ \\
\hline Serous carcinoma - Low grade & 20 & $29.0 \%$ \\
\hline Serous carcinoma - High grade & 4 & $5.8 \%$ \\
\hline Mucinous carcinoma & 5 & $7.2 \%$ \\
\hline Clear cell carcinoma & 4 & $5.8 \%$ \\
\hline Sertoliformendometrioid carcinoma & 1 & $1.4 \%$ \\
\hline Endometrioid adenocarcinoma & 9 & $13.0 \%$ \\
\hline Malignant Brenner tumour & 1 & $1.4 \%$ \\
\hline Malignant mixed surface epithelial tumor & 4 & $5.8 \%$ \\
\hline SEX CORD STROMAL TUMORS & $\mathbf{1 3}$ & $18.8 \%$ \\
\hline Adult granulosa cell tumour & 9 & $13.0 \%$ \\
\hline Fibrosarcoma & 1 & $1.4 \%$ \\
\hline Steroid cell tumour & 1 & $1.4 \%$ \\
\hline Sex chord stromal tumour unclassified & 1 & $1.4 \%$ \\
\hline Poorly differentiated Sertolileydig cell tumour & 1 & $1.4 \%$ \\
\hline GERM CELL TUMORS & $\mathbf{8}$ & $11.6 \%$ \\
\hline Immature teratoma & 3 & $4.3 \%$ \\
\hline Dysgerminoma & 3 & $4.3 \%$ \\
\hline Yolk sac tumour & 1 & $1.4 \%$ \\
\hline Malignant Mixed germ cell tumor & 1 & $1.4 \%$ \\
\hline TOTAL & $\mathbf{6 9}$ & $100.0 \%$ \\
\hline
\end{tabular}


Table (4) Frequency of benign, borderline and malignant tumors in the three major tumor histological groups

\section{Table 4}

\begin{tabular}{|lccccc|}
\hline CATEGORY & SET & SCST & GCT & TOTAL & $\%$ \\
\hline BENIGN & 350 & 12 & 144 & 506 & $85.0 \%$ \\
\hline BORDERLINE & 20 & 0 & 0 & 20 & $3.4 \%$ \\
\hline MALIGNANT & 48 & 13 & 8 & 69 & $11.6 \%$ \\
\hline TOTAL & 418 & 25 & 152 & 595 & $100 \%$ \\
\hline$\%$ & $70.3 \%$ & $4.2 \%$ & $25.5 \%$ & $100.0 \%$ & \\
\hline
\end{tabular}

\section{Discussion}

Ovarian tumors manifest a wide spectrum of clinical, morphological, histological features. The clinicopathological profile of the ovarian tumors diagnosed in our institution during the study period were analyzed. The clinical parameters like age, presenting symptoms were compared in relation to the histological type of the tumors. Clinical and histopathological findings of these tumors were analyzed and correlated with different studies. According to studies, the frequency of benign lesions was more compared to malignant lesions of the ovary. Our study also shows similar observation. In the present study 506 cases $(85 \%)$ were benign, borderline tumors 20 cases $(3.34 \%)$ and malignant 69 cases $(11.6 \%)$. This is similar to studies conducted by Gupta et $\mathrm{al}^{(8)}$, Jha and Karki etal ${ }^{(9)}$, Kuladeepa etal ${ }^{(10)}$ and Sohail etal ${ }^{(11)}$

\section{Table 5}

\begin{tabular}{|l|c|c|c|}
\hline Study & Benign \% & Borderline \% & Malignant $\%$ \\
\hline Gupta et al & 72.9 & 4.1 & 22.9 \\
\hline Jha\&Karki et al & 83.9 & - & 16.1 \\
\hline Kuladeepa et al & 82.35 & 3.68 & 13.97 \\
\hline Sohail et al & 74.8 & 1.6 & 23.4 \\
\hline Present study & $\mathbf{8 5}$ & $\mathbf{3 . 4}$ & $\mathbf{1 1 . 6}$ \\
\hline
\end{tabular}

In the present study 570 cases $(95.48 \%)$ were unilateral and 27 cases $(4.52 \%)$ were bilateral. This is similar to studies conducted by
Prabhakaran et $\mathrm{al}^{(12)}$, Misra etal ${ }^{(13)}$, Couto $\mathrm{F}$ et $\mathrm{al}^{(14)}, \mathrm{Kar}_{\mathrm{etal}}{ }^{(15)}$

\section{Table 6}

\begin{tabular}{|l|c|c|}
\hline Study & Unilateral \% & Bilateral \% \\
\hline Prabhakaran et al & 90.9 & 9.1 \\
\hline Misra et al & 95.5 & 4.5 \\
\hline Couto F et al & 91.2 & 8.7 \\
\hline Kar et al & 73.13 & 26.8 \\
\hline Present study & $\mathbf{9 5 . 4 8}$ & $\mathbf{4 . 5 2}$ \\
\hline
\end{tabular}

Ovarian tumors may occur at any age including infancy and childhood. In the present study, ovarian tumors were common in the age group 40$49 \mathrm{yrs}$. The youngest patient in our study was $5 \mathrm{yr}$ old with benign mature cystic teratoma and the oldest was an $83 \mathrm{yr}$ old patient with mucinous cystadenoma.
Histopathologically surface epithelial tumors were the most common category of ovarian tumors encountered in our study (70.3\%) followed by germ cell tumor $(25.5 \%)$, sex cord stromal tumors (4.2\%). Similar observations were made by Swamy and Satyanarayana ${ }^{(16)}$ and Pilli et $\mathrm{al}^{(17)}$. The most common surface surface epithelial 
tumor was serous cystadenoma 219 cases (36.68\%) followed by mucinous cystadenoma 11cases $(19.6 \%)$. This was similar to studies reported by Yasmin et al ${ }^{(18)}$ in her study.

Among benign tumors most common was serous cystadenoma which constituted 219 cases. $(43.28 \%)$ and the least common was benign Brenner tumor 3 cases $(0.59 \%)$. Among the borderlinetumor, commonest tumor in our study was Mucinous borderline tumors 17 cases (85\%). In the category of malignant tumors in our study, most common was low grade serous carcinoma 20 cases $(29 \%)$

Metastasis constituted only two cases. One case was metastasis from carcinoma colon and other from endometrial carcinoma uterus. Common clinical presentation in this study for both benign and malignant lesions was pain abdomen in 242 cases $(40.1 \%)$ followed by mass abdomen in 100 cases $(16.86 \%)$. Other common complaints encountered were bleeding pv, menstrual abnormalities, post menopausal bleeding, backache, abdominal distension. In 7\%of cases, it was incidentally detected during antenatal checkup and infertility treatment.

Among the benign surface epithelial tumors most common was serous cystadenoma 219 cases (43.28 \%), mucinous cystadenoma 117 cases (23.1\%) cases, then seromucinous cystadenoma and benign Brenner tumor. The ovarian tumors encountered in sex cord stromal tumor group was fibrothecoma and fibroma. Among germ cell tumors most common was benign mature cystic teroma 144 cases $(28.45 \%)$. This was comparable to similar studies by Shardha Go et al ${ }^{(19)}$. Among the borderline tumors, Mucinous borderline tumor was the commonest. Seromucinous borderline tumor and endometrioid adenofibroma borderline were the other tumors encountered. Malignant tumors (48 cases) there were serous carcinoma high grade, low grade, Mucinous carcinoma, clear cell carcinoma, sertoliform endometrioid adenocarcinoma, malignant Brenner tumor, malignant mixed surface epithelial tumor. Included in the malignant sex cord stromal tumors were Adult granulosa cell tumor, fibrosarcoma, steroid cell tumors, sex cord tumors unclassified and poorly differentiated sertoli leydig cell tumors. Malignant germ cell tumors accounted for $11.6 \%$ (8 cases) which included immature teratoma, dysgerminoma, yolk sac tumor and malignant mixed germ cell tumors.

Inspite of the increasing incidence, morbidity and mortality due to ovarian malignancy, the etiology is poorly understood. Risk factors include family history, usage of drugs used for ovulation induction. Protective factors include increased parity, oophorectomy, tubal ligation. American college of Obstetrics and Gynecology in 2005 has suggested that prophylactic salpingectomy may offer protection against ovarian tumors instead of oophorectcomy $^{(20)}$.

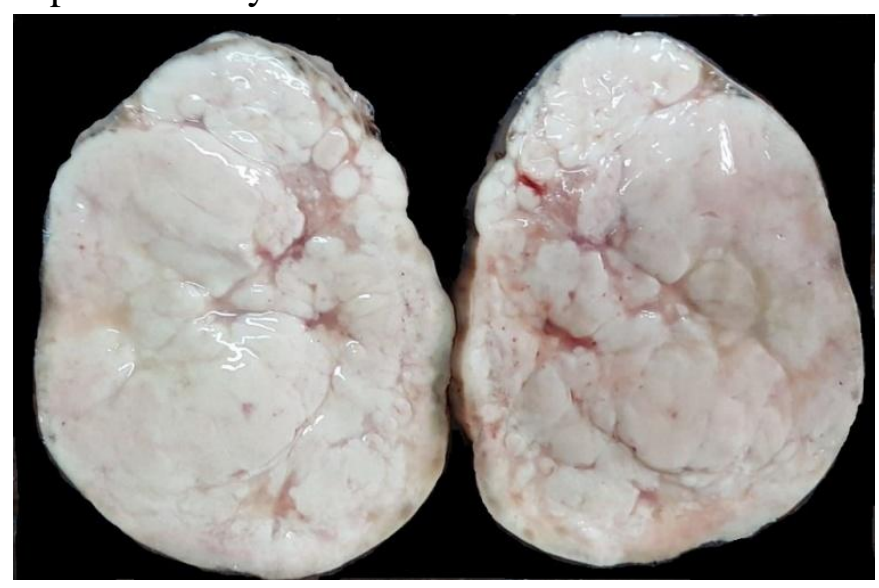

Figure 5- Gross Dysgerminoma- Homogenous solid fleshy lobulated.

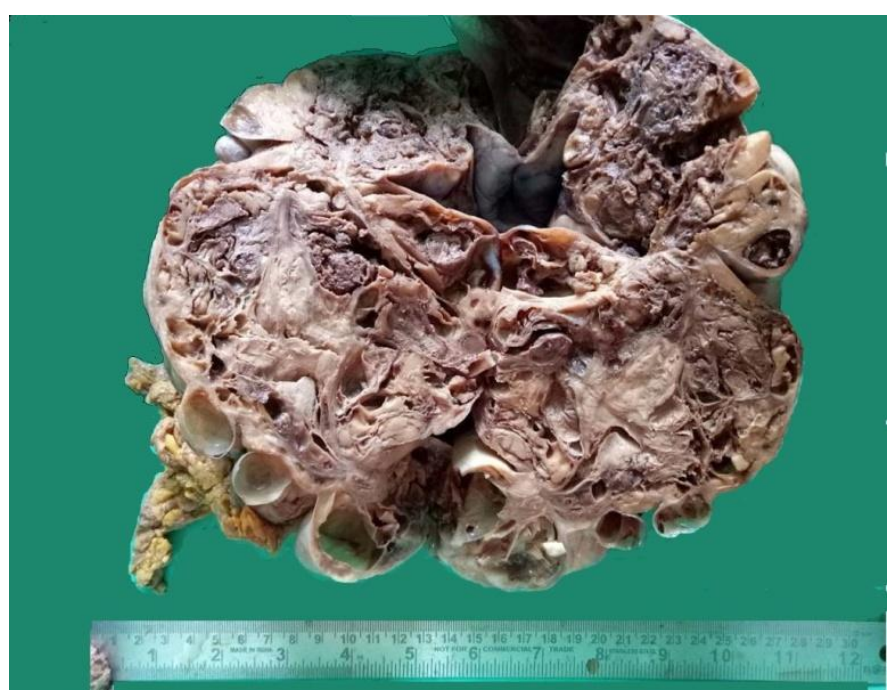

Figure 6- Gross High grade serous carcinomaSolid and cystic with granular surface 


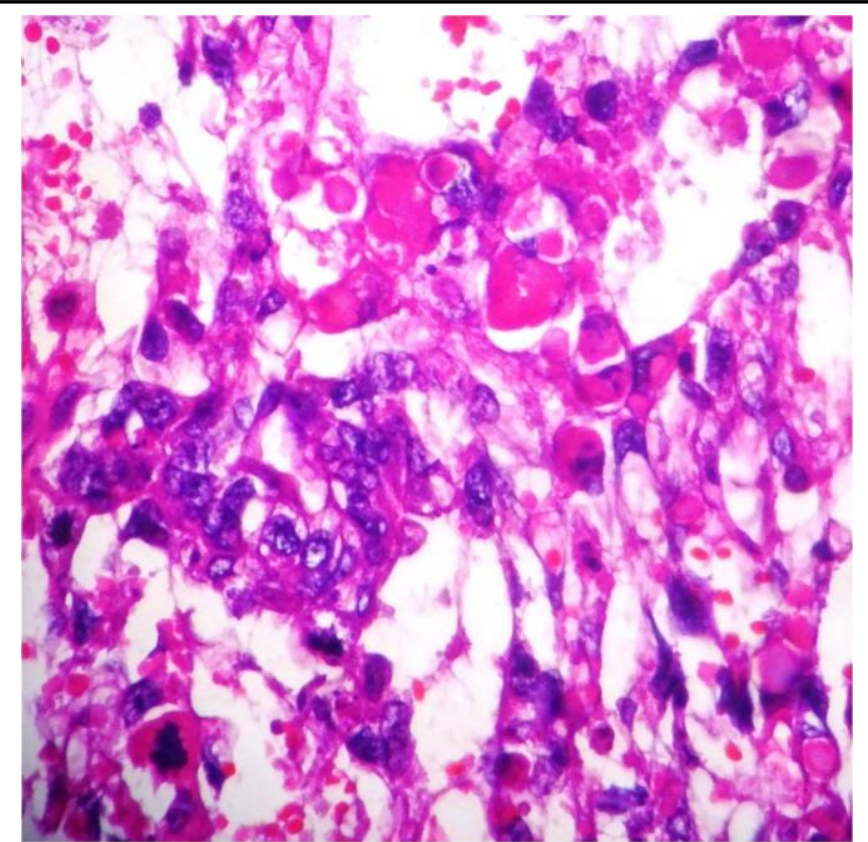

Figure 7.Microscopy Yolk sac tumor with hyaline globules

\section{Conclusion}

The study was conducted in Government Medical College Thiruvananthapuram from Jan 2015 Dec 2016 for a period of two years which included 597 specimens. Benign ovarian tumors outnumbered malignant tumors. Most common histological types were surface epithelial tumors followed by germ cell tumors and the least common was metastasis. The commonest age group of ovarian tumors was $40-49$ years. Pain abdomen and mass abdomen were the most common clinical presentations for both benign and malignant ovarian tumors.

Though the imaging techniques and clinical examination helps in detection of ovarian tumors, histopathological examination remains the gold standard for typing of ovarian tumors.

\section{References}

1. Basu P, De P, Mandal S, Ray K, Biswas J. Study of'patterns of care'of ovarian cancer patients in a specialized cancer institute in Kolkata, eastern India. Indian journal of cancer. 2009 Jan 1;46(1):28.-33 Cross ref

2. Young R.H. The ovary. In : Sternberg's diagnostic surgical pathology $17^{\text {th }}$ ed. New York Raven Press;1994 p2195
3. Sikdar K, Kumar P, Roychowdhary NN. A study of ovarian malignancy: A review of 149 cases. J ObstetGynaecol India. 1981 ;30:478-80

4. Rosai . J. Female reproductive system: Ackerman's surgical pathology, $8^{\text {th }}$ edition. Mosby - year book Inc . Newyork; 1996 p1473 - 539.

5. Modan B, Hartge P, Hirsh-Yechezkel G, Chetrit A, Lubin F, Beller U, Ben-Baruch G, Fishman A, Menczer J, Struewing JP, Tucker MA. Parity, oral contraceptives, and the risk of ovarian cancer among carriers and noncarriers of a BRCA1 or BRCA2 mutation. New England Journal of Medicine. 2001 Jul 26;345(4):235-40.

6. Clement PB., Young RH. Ovarian Surface Epithelial - Stromal Tumors. In: Mills SE, editor. Sternberg's Diagnostic Surgical Pathology. 5 th ed. Philadelphia: Lippincott Williams and Wilkins, 2004. 2278-2308

7. Tavassoli FA, Deville P, World Health Organization classification of tumors. Pathology and genetics of the tumors of breast and female genital organs. Lyon: IARC press; 2003. p. 113-96

8. Gupta N, Bisht D, Agarwal AK, Sharma VK. Retrospective and prospective study of ovarian tumours and tumour-like lesions. Indian journal of pathology \& microbiology. 2007 Jul;50(3):525-7.

9. Jha R, Karki S. Histological pattern of ovarian tumors and their age distribution. Nepal Med Coll J. 2008 Jun;10(2):81-5.

10. Kuladeepa AV, Muddegowda PH, Lingegowda JB, Doddikoppad MM, Basavaraja PK, Hiremath SS. Histomorphological study of 134 primary ovarian tumours. Adv Lab Med Int. 2011;1(4):69-82.

11. Sohail I, Hayat Z, Saeed S. A comparative analysis of frequency and patterns of ovarian tumours at a tertiary care hospital between two different study periods (2002- 
2009). Journal of Postgraduate Medical Institute (Peshawar-Pakistan). 2012 Mar 23;26(2).

12. Prabhakar BR, Maingi K. Ovarian tumours--prevalence in Punjab. Indian journal of pathology \& microbiology. 1989 Oct;32(4):276-81.

13. Mishra RK, Sharma SP, Gupta U, et al. Pattern of ovarian neoplasm in eastern UP. J ObstetGynaecol India 1991;30:242-6.

14. Couto F, Nadkarni NS, Jose M. Ovarian tumours in Goa: A clinicopathological study. J ObstetGynecol India. 1993;40(2):408-11.

15. Kar, T., Kar, A. and Mohapatra, P.C. IntraOperative Cytology of Ovarian Tumors. The Journal of Obstetrics and Gynecology of India, 2005), 55, 345-349.

16. Swamy GG, Satyanarayana N. Clinicopathological analysis of ovarian tumours: a study on five years samples. Nepal Med Coll J. 2010 Dec;12(4):221-3.

17. Pilli GS, Suneeta KP, Dhaded AV, Yenni VV. Ovarian tumours: a study of 282 cases. Journal of the Indian Medical Association. $2002 \mathrm{Jul}$;100(7):420-3.

18. Yasmin S, Yasmin A, Asif $M$. Clinicohistological pattern of ovarian tumours in Peshawar region. J Ayub Med Coll Abbottabad. 2008 Dec 1;20(4):11-3.

19. Sharadha SO, Sridevi TA, Renukadevi TK, Gowri R, Binayak D, Indra V. Ovarian masses: changing clinico histopathological trends. The Journal of Obstetrics and Gynecology of India. 2015 Feb 1;65(1):34-8.

20. American College of Obstetricians and Gynecologists. Salpingectomy for ovarian cancer prevention. Committee opinion no. 620. Obstet Gynecol. 2015;125:279-81. 